\title{
Calorie Thresholds and Undernutrition in India, 1993-2004
}

\author{
Nidhi Kaicker \\ Faculty of Management Studies, \\ University of Delhi \\ \& \\ Raghav Gaiha \\ Department of Global Health and Population, \\ Harvard University, and \\ Visiting Fellow ASARC and \\ Professor Faculty of Management Studies, \\ University of Delhi
}

\begin{abstract}
In a recent study, Jensen and Miller (2011) propose a new measure of undernutrition, based on a calorie share of staples threshold. Among the merits of this measure are that (i) it dispenses with calorie norms, and (ii) relies on a behavioural approach to estimate this threshold. What our analysis with Indian household data for 1993 and 2004 points to is that the Jensen-Miller (2011) story is of limited interest and potentially misleading principally because it confines variation in calorie share to a measure of wealth. The calorie threshold is suspect as it is influenced by several other factors-especially food prices-that are omitted. Since even acutely poor substitute in response to changes in food prices, calorie and income thresholds change, and, consequently, the estimates of undernourished. In some cases, the divergences are large. Thus, both the predictive accuracy of the measure proposed and its descriptive richness leave a lot to be desired.
\end{abstract}

Key words: calories, staples, undernutrition, wealth, food prices, India.

JEL Codes: I12,I15 and D12.

Corresponding Author: Raghav Gaiha <raghavdasgaiha@gmail.com> 


\section{Calorie Thresholds and Undernutrition in India, 1993-2004 ${ }^{1}$}

\section{Introduction}

Various studies point to a puzzle. In India, despite rising incomes, there has been a sustained decline in per capita calorie intake. In an important contribution, Deaton and Dreze (2009) offer a detailed analysis of this decline over the period 1983 to 2004. The average calorie consumption was about 10 per cent lower in rural areas in 2004-05 than in 1983. The proportionate decline was larger among the more affluent sections of the population, and about 0 for the bottom quartile of the per capita expenditure scale. In urban areas, there was a slight change in average calorie intake over this period. Moreover, the decline of per capita consumption also applies to proteins and other nutrients, with the exception of fats whose consumption has increased in both rural and urban areas over this period.

As incomes rose over this period, these declines are puzzling. A more contentious view offered by Deaton and Dreze (2009) is that the latter are not attributable to changes in relative prices as an aggregate measure of the price of food - treated synonymous with the price of calories - changed little during the period in question. Per capita calorie consumption is lower at a given level of per capita household expenditure, across the expenditure scale, resulting in a steady downward shift of the calorie Engel curve. ${ }^{2}$ Deaton and Dreze (2009) are emphatic that the downward shift is due to lower calorie requirements, associated mainly with better health and lower activity levels. As the evidence offered is fragmentary and patchy, this explanation is largely conjectural.

If the proportions of undernourished are measured using fixed calorie norms, there is an increase in the prevalence of undernutrition (synonymous with calorie-deprivation). Even if the calorie norms are taken to be lower, as illustrated later, a grim picture emerges. A recent contribution (Jensen and Miller, 2011) is deeply sceptical of such norms for familiar reasons ${ }^{3}$ and proposes an alternative measure that relies on consumption behaviour, as opposed to calorie norms. The basic argument is that individuals tend to switch away from the cheapest source of calories (staple food sources), after surpassing subsistence, towards more expensive

\footnotetext{
${ }^{1}$ Gaiha would like to thank David Bloom for the invitation to work at Harvard's Department of Global Health and Population during the summer of 2011 and for his valuable suggestions and support throughout this study. We are also grateful to C.P. Timmer, Anil Deolalikar, Raghbendra Jha, Prabha Sharma, Varsha S. Kulkarni, R. Jensen and Raj Bhatia for their constructive suggestions. All remaining errors are, however, the sole responsibility of the authors.

2 There is some variation over the period 1993-2004, as illustrated graphically later.

${ }^{3}$ Refer to Section 4 for a discussion
} 
sources of calories. If this switch occurs at a certain share of calories from staples, all those above the threshold are counted as undernourished. An application to China reveals a huge difference between proportions of undernourished measured using fixed calorie norms and the behavioural approach just delineated.

This motivated our analysis with the National Sample Survey data for 1993 and 2004. As the continuing food price spiral has reignited fears of another crisis with dire consequences for the poor, it is vital for policy purposes to get the measurement of undernutrition right. This concern is reinforced by a national debate on universalising the food subsidy through the public distribution system (PDS). While the case for a universal food subsidy is weak and controversial given huge losses from the PDS, food security nevertheless remains an overriding policy concern. In what follows, we will first review the evidence on undernutrition over the period 1993-2004, using NSS rural and urban samples. This is followed by a review of the Jensen-Miller study (2011) in Section III, and some analytical and interpretational issues in Section IV. Our methodology and the results are discussed in Section V. As the thresholds of calorie shares vary and the numbers above them, depending on the specification used, serious doubts arise about the applicability and usefulness of the Jensen-Miller (2011) behavioural approach. Concluding observations from a broad policy perspective are given in Section VI.

\section{Changes in Calorie Intake ${ }^{4}$}

Until recently, a calorie intake of 2400 per day was considered adequate for a typical adult engaged in physically strenuous work of certain duration in rural India (2100 calories per person per day in urban India). More recent assessments have converged to lower calorie 'requirements' (1800 calories per person per day in rural areas and 1700 per person per day in urban areas). ${ }^{5}$

Table 1 shows the calorie intake distribution in rural India for 1993 and 2004. The proportion of undernourished rises from 71 per cent in 1993 to nearly 80 per cent in 2004, if we consider the higher cut-off of 2400 calories. But, the proportion below the lower cut-off also rises from about 31 per cent to close to 37 per cent. By any standard, these imply high estimates of calorie deprivation.

\footnotetext{
${ }^{4}$ This draws upon Gaiha et al. (2010).

${ }^{5}$ Srinivasan (1992) is deeply sceptical of such requirements on the grounds that energy expenditure adjusts to intake within a range.
} 
Table 1

Calorie Intake Distributions in Rural India, 1993-2004

\begin{tabular}{|c|c|c|c|c|c|}
\hline \multirow{2}{*}{ Year } & \multicolumn{4}{|c|}{ Range of Calorie Intake Per Capita Per Day } & \multirow{2}{*}{ Total } \\
\cline { 2 - 5 } & $<1800$ & $1801-2400$ & $2401-3000$ & $>3000$ & \\
\hline \multirow{3}{*}{1993} & $\begin{array}{c}31.09 \\
(1491)\end{array}$ & $\begin{array}{c}40.07 \\
(2084)\end{array}$ & $\begin{array}{c}19.42 \\
(2650)\end{array}$ & $\begin{array}{c}9.42 \\
(3636)\end{array}$ & $\begin{array}{c}100 \\
(2156)\end{array}$ \\
\hline \multirow{2}{*}{2004} & $\begin{array}{c}36.68 \\
(1516)\end{array}$ & $\begin{array}{c}43.11 \\
(2071)\end{array}$ & $\begin{array}{c}15.07 \\
(2629)\end{array}$ & $\begin{array}{c}5.14 \\
(3925)\end{array}$ & $\begin{array}{c}100 \\
(2047)\end{array}$ \\
\hline
\end{tabular}

Source: NSS

Table 2

Calorie Intake Distributions in Urban India, 1993-2004

\begin{tabular}{|c|c|c|c|c|c|}
\hline \multirow{2}{*}{ Year } & \multicolumn{4}{|c|}{ Range of Calorie Intake Per Capita Per Day } & \multirow{2}{*}{ Total } \\
\cline { 2 - 5 } & $<1700$ & $1701-2100$ & $2101-2600$ & $>2600$ & \\
\hline \multirow{2}{*}{1993} & $\begin{array}{c}28.12 \\
(1426)\end{array}$ & $\begin{array}{c}29.62 \\
(1900)\end{array}$ & $\begin{array}{c}25.76 \\
(2320)\end{array}$ & $\begin{array}{c}16.49 \\
(3107)\end{array}$ & $\begin{array}{c}100 \\
(2074)\end{array}$ \\
\hline \multirow{2}{*}{2004} & $\begin{array}{c}29.40 \\
(1440)\end{array}$ & $\begin{array}{c}34.52 \\
(1900)\end{array}$ & $\begin{array}{c}24.67 \\
(2313)\end{array}$ & $\begin{array}{c}11.41 \\
(3252)\end{array}$ & $\begin{array}{c}100 \\
(2021)\end{array}$ \\
\hline
\end{tabular}

Source: NSS

Table 2 contains estimates for urban India. Assuming lower calorie norms of 1700 and 2100 (given less strenuous physical activity in urban areas) per person per day, more than a quarter of the households (about 28 per cent) consumed less than 1700 calories in 1993. More than twice this proportion (about 58 per cent) were below the higher calorie norm of 2100. Thus well over half of the urban households were deprived in terms of calorie intake. Worse, this proportion rises to about 64 per cent over the period 1993-2004. While this is much less alarming than the calorie deprivation increase in rural India, it is nevertheless worrying.

In case of proteins, although the mean per capita intake remained unchanged, there has been an increase in the proportion of households consuming less than the minimum requirements. It is noteworthy that well over 57 percent of rural households consumed fewer than the required protein intake (60 gms) in 1993. In fact, just under a quarter of the households consumed $<45$ (gms) of protein. Although the share of protein-deficient urban households in urban India rose slightly (from about 62.67 per cent to about 64 per cent), the share below the lower cut-off of 45 (gms) rose more than moderately (from about 25 per cent to over 29 per cent). 
The proportion of households in rural India consuming less than the minimum fat requirements (less than 20 gms) fell sharply (from over 34 per cent to well over 22 per cent). But the mean fat intakes remained unchanged. Similar results are found for urban India.

In brief, taking the norms as valid, the overall picture of nutritional deprivation worsened considerably over the period 1993-2004.

Some additional comments on the decline in calorie intake are necessary, as illustrated graphically in Figs: $1-4$.

Figure 1: Calorie Engel Curve (Rural India)

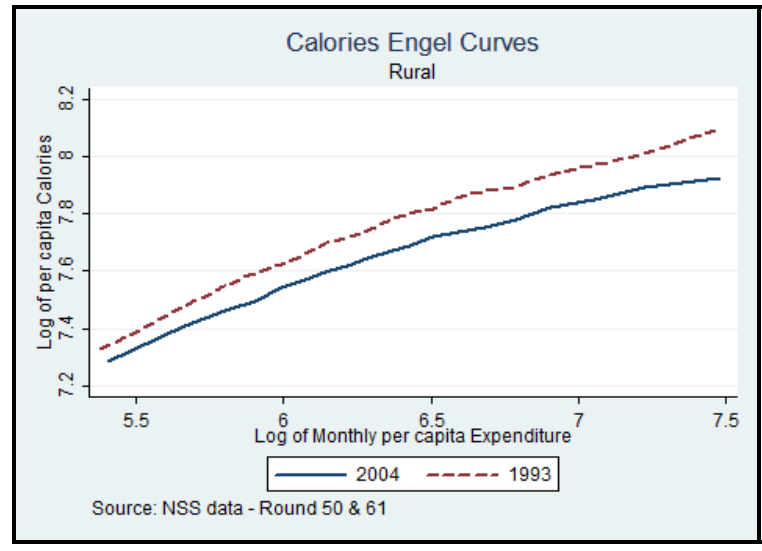

Figure 3: Cereal Calorie Engel Curve (Rural India)

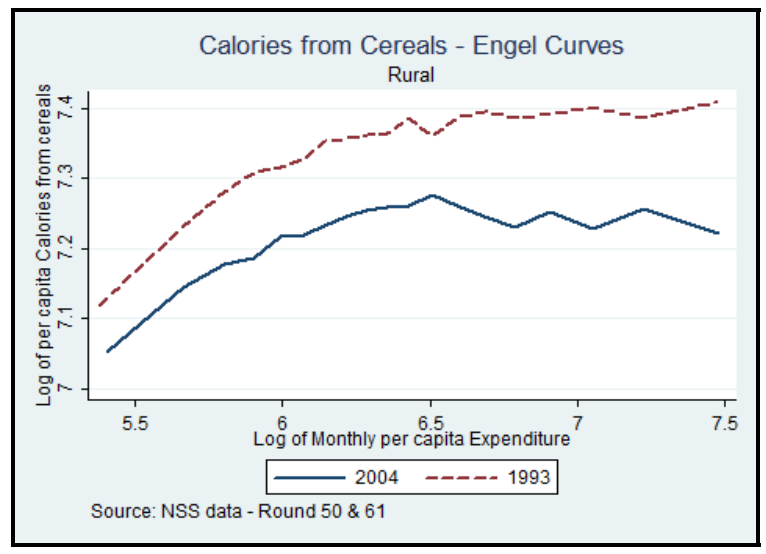

Figure 2: Calorie Engel Curve (Urban India)

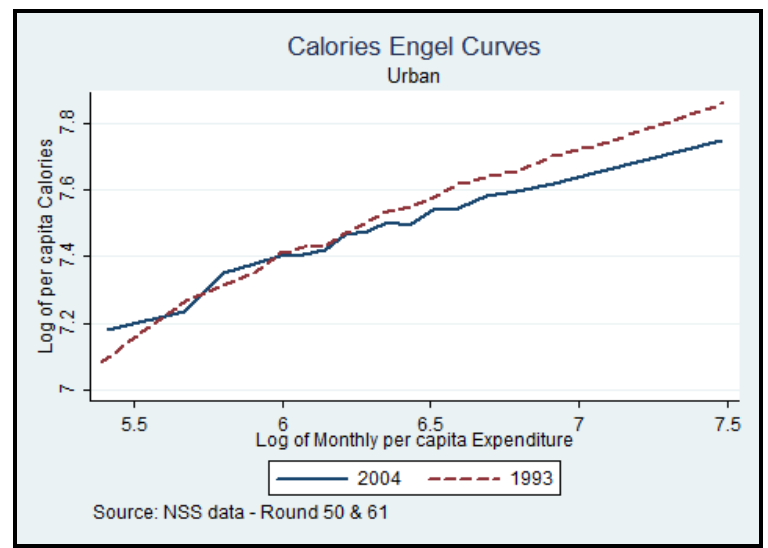

Figure 4: Cereal Calorie Engel Curve (Urban India)

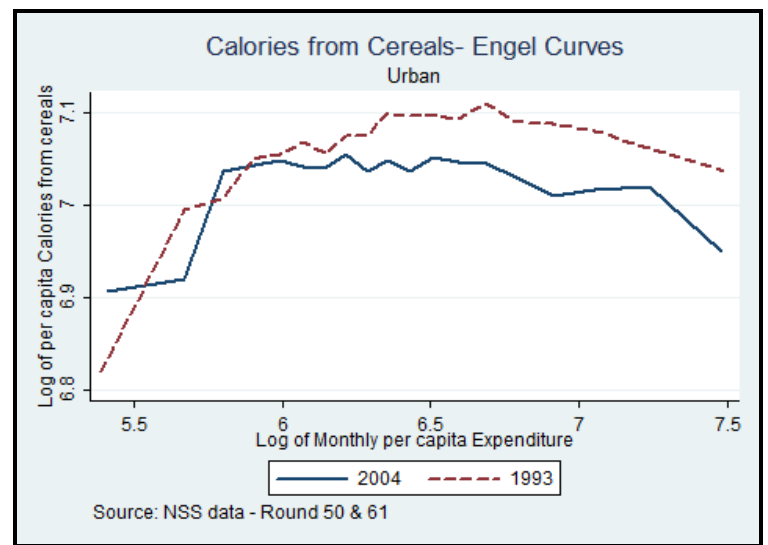

In rural India, the total calorie curve shifted downward in a parallel way over the period 1993-2004, so that the percentage decline in calories did not differ much between the poor and rich (defined holding per capita expenditure fixed). By contrast, in urban India, the 
downward shift was larger among the better-off, with two points of intersection at low expenditure levels. ${ }^{6}$

There were significant differences in the decline in calories from cereals. In rural India, the decline in cereal calories over the period 1993-2004 was much sharper among the better-off. In urban India too, the better-off recorded larger reductions in cereal calories than those lower down on the MPCE or expenditure scale (used synonymously with income). ${ }^{7}$

\section{Calorie Thresholds}

Jensen and Miller (2011) invoke several familiar arguments against using fixed calorie norms. These include: (i) lack of a consensus on what the correct minimum calorie threshold is, how it should be computed or even whether such a threshold exists (Dasgupta, 1995, Srinivasan, 1993, and Svedberg, 2000). (ii) As calorie norms vary by age, sex, health status, activity patterns, and basal metabolic rate — some of which are unobservable or too difficult to measure - use of standardised norms to measure undernutrition is problematic. (iii) Not all nutrients consumed are absorbed before leaving the body. One difficulty in absorption is high incidence of diseases such as diarrhoea. But even in the absence of such diseases, absorption rates vary between individuals. This introduces a 'noise' in the measurement of undernutrition, as individuals may appear to consume far more than their 'true needs' but absorbing only a fraction of that amount. (iv) There is a large literature confirming that, as household incomes rise, households tend to substitute towards foods with non-nutritional attributes (e.g. taste for variety). ${ }^{8}$ Such behaviour reflects a weaker preference for calories than for taste.

Jensen and Miller (2011) accordingly propose and implement an alternative measure based on calorie share of staples threshold. This is rationalised on the following grounds: (i) An individual before attaining this threshold experiences physical sensations of hunger: headaches, pain, dizziness, and failure to concentrate. (ii) As the marginal utility of additional calories is high, a utility maximising consumer concentrates on consuming calories from the cheapest sources (rice, wheat or cassava). However, after crossing the calorie threshold at higher wealth, the consumer begins to substitute towards more expensive sources of calories

\footnotetext{
${ }^{6}$ In the Deaton-Dreze (2009) graphs, the urban calorie Engel curve for 2004 is lies below that for 1993. However, the former is truncated at the lower end at a higher expenditure. As our graphs are constructed from 20 expenditure intervals with median expenditure and calorie intake, some differences cannot be ruled out.

${ }^{7}$ The two cereal calorie Engel curves intersect at low expenditure levels, as in Deaton and Dreze (2009).

${ }^{8}$ For an insightful exposition, see Behrman and Deolalikar (1989).
} 
(i.e. meat, fruits and vegetables) and a more varied diet. Thus, at the threshold, the marginal utility of calories is low and subsistence is surpassed.

Apart from overcoming the difficulties arising from individual-specific and unobservable subsistence thresholds, it is claimed that the proposed measure has the merit of being consistent with revealed consumer preferences and greater intuitive public policy appeal. The latter lies in a shift from calories to utility.

Jensen and Miller (2011) point out that this threshold matches that computed from the minimum cost diet problem, subject of course to the caveat that such diets are seldom consumed by the impoverished (Deaton, 1995). Besides, they report that their threshold is very stable with respect to factors such as age, height, weight and activity level. So, based on their analysis with Chinese data, the threshold follows a tight range that helps "identify hunger across all individuals, regardless of their attributes” (p. 4).

There are a few limitations of this measure, however. These include (i) omission of other nutrients, (ii) failure to account for long-term adjustment of the human body to nutritional deprivation, and (iii) lack of sensitiveness to the depth of deprivation.

As argued and illustrated below, there appear to be more serious flaws in this measure.

\section{Issues}

In trying to replicate and refine the Jensen and Miller (2011) results, we first employ Lowess regressions of calorie share of cereals (wheat, rice and inferior cereals that account for a large share of total calories) on a measure of wealth (monthly per capita expenditure), followed by an expanded specification in which, along with food prices, demographic and caste variables are used as explanatory variables. ${ }^{9}$ Changes in the calorie share thresholds and corresponding expenditures/incomes are striking. More striking are the changes in the proportions of undernourished.

While the Lowess results, as discussed later, largely corroborate the Jensen-Miller hypothesis, they raise a few analytical concerns discussed below.

\footnotetext{
${ }^{9}$ In rural India in 1993, cereals accounted for about 71 per cent of total calories while in 2004 the corresponding share dropped to about 68 per cent (Gaiha et al. 2010).
} 
i. Underlying the empirical analysis is a utility maximising model, net of a penalty function, with a budget constraint. ${ }^{10}$ The reduced form of calorie share as a function of wealth (approximated by income) estimated using Lowess suggests that over a range of wealth the consumer prefers staples to any other food commodity until the threshold level is reached. Arguably, this is also consistent with lexicographic ordering of consumer preferences for staples. In that case, following Cantor's theorem, it cannot be represented by a real valued utility function.

ii. In an important paper, Timmer (1981) estimated curvature in the Slutsky matrix, based on the 1976 Socio-Economic Survey-Susenas V-for Indonesia. Or, more specifically, the question addressed is whether the Slutsky substitution elasticities vary by income class? Whether the poor exhibit higher or lower substitution elasticities than others in a context of spiralling food prices - ignored in the JensenMiller analysis (2011) — is of considerable significance in understanding the extent and severity of undernutrition. If the poor do, in fact, substitute between food commodities when relative prices change, the calorie staple threshold must reflect the influences of wealth and food prices, among others. The findings corroborate curvature in the Slutsky matrix. To illustrate, the cassava-rice elasticities are positive and decline sharply with income. Extending this analysis to calories obtained from rice, cassava and shelled corn, the compensated own-price response by income class does not fit this pattern. The poorest segment of the Indonesian population, with the least adequate calorie intake, did not show any compensated price reaction to calorie prices despite highly significant responses to price changes for the commodities individually. However, for the remaining three income classes, low-middle, highmiddle and high, the (absolute) price responses decline. The somewhat intriguing result for low income households may, however, change if calories from individual commodities are considered separately. So, in large measure, the poor are more responsive to food price changes.

\footnotetext{
${ }^{10}$ The utility function $\mathrm{u}\left(\mathrm{x}_{1}, \mathrm{x}_{2}\right)$ is a standard utility function minus a penalty function, $\mathrm{f}($.$) , maximised subject to$ a wealth/budget constraint . u (.) is assumed to be homothetic. This implies that the marginal rate of substitution between $\mathrm{x}_{1}$ and $\mathrm{x}_{2}$ depends only on their ratio, $\mathrm{x}_{1} / \mathrm{x}_{2} . \mathrm{f}($.) represents a penalty function that is decreasing and convex. Letting $\mathrm{z}=\mathrm{c}_{1} \mathrm{x}_{1}+\mathrm{c}_{2} \mathrm{x}_{2}-\mathrm{s}$, where $\mathrm{x}_{1}$ and $\mathrm{x}_{2}$ are two food commodities, $\mathrm{c}_{1}$ and $\mathrm{c}_{2}$ denote their calorie content, and $\mathrm{s}$ is a constant that captures subsistence calories, it is further assumed that $\mathrm{f}^{\prime}(\mathrm{z})$ increases to 0 as $\mathrm{z}$ increases above 0 and decreases to negative infinity as $\mathrm{z}$ decreases below 0 . When the consumer is sufficiently wealthy, $\mathrm{f}^{\prime}(\mathrm{z})$ will approach 0 , and so the consumer behaves approximately as if he maximises $\mathrm{u}(\mathrm{x})$ subject to the budget constraint. However, at low wealth, the consumer finds it difficult to afford a bundle with $\mathrm{z}>0$. and behaves approximately as if he maximises calories subject to the budget constraint (Jensen and Miller, 2011).
} 
iii. In another important contribution, Behrman and Deolalikar (1989) examine the conjecture that food variety per se is valued so that people purchase food variety as their incomes rise while calorie intakes change slightly. They focus on two characteristics of consumer preferences over different foods: the degree of curvature and centrality (relative to the axes) of the location of food indifference curves. If low cost calories dominate food choices at very low incomes, the food indifference curves are likely to be relatively flat (so price induced substitution is high) and located closer to the axis for the cheapest source of calories. As incomes and food budgets increase, food indifference curves may be more sharply curved and centred far away from the cheapest source of calories' axis. A situation of greater curvature and locational centrality of food indifference curves is characterised as "a taste for food variety" (p. 667). The analysis is based on the ICP data on 34 countries for 1975 and on 60 countries for 1980. Two results are particularly relevant here. (i) The elasticity of substitution across nine different foods is 1.25 for the poorest subsample of countries, implying that the food indifference curves are considerably flatter than the CobbDouglas case. However, for the next subsample, the elasticity of substitution falls sharply to 0.28 , indicating greater curvature of the food indifference curves. Hence as food budgets increase, demand for food variety rises, with the food indifference curves changing from flat to being L-shaped. (ii) The implied (relative pricesconstant) ratios of breads/cereals to most other foods consumed either falls or remains unchanged between the poorest subsample and the next. Since breads/cereals are the cheapest source of calories, it follows that as food expenditures and incomes increase from very low levels, there is evidence of a locational shift of the food indifference curves away from the axis of the cheapest source of calories and towards other foods given constant relative prices. Two points emerge from this analysis: one is a strong relative price effect among the poor, and the other is the strong income effect. Neglect of the former in the Jensen-Miller analysis (2011) is thus limiting.

iv. Characterisation of the undernourished as those with calorie share of staples above the threshold is somewhat arbitrary and ambiguous. Consider Figure 5 that resembles the Lowess curves reported in Jensen and Miller (2011). 
Figure 5: Staple Calorie Share and Wealth

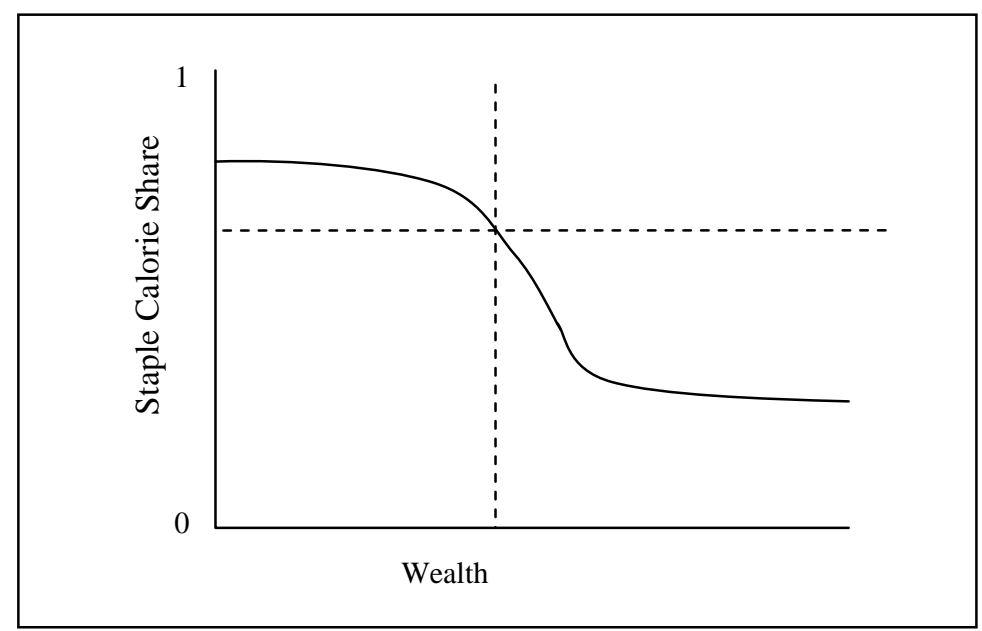

As also illustrated with India's NSS data, there are four sections comprising: households/individuals below the calorie threshold and to the left of the corresponding wealth (generally very low); those above the calorie threshold but to the left of the corresponding wealth; those below the threshold and to the right of the corresponding wealth, and those above the threshold but to the right of the corresponding wealth; and others. Jensen and Miller (2011) take the fraction of the population above the calorie threshold as the undernourished. The level of wealth/income corresponding to the calorie threshold ceases to have any significance as all those on either side of the wealth cut-off but above the calorie threshold are added up. Failure to distinguish between the undernourished because of extremely low wealth and those not so constrained by it limits the policy significance of the new measure proposed. What is also worrying is exclusion of those below the calorie threshold and to the left of the corresponding wealth. In so far as their wealth is extremely low, and, consequently, also their consumption of cereals and calories, their exclusion from the undernourished is far from self-evident. As graphs for India reveal, even though their numbers are small, their calorie share seems to rise with wealth (or monthly per capita expenditure). If there is a continuum of the undernourished sacrificed in constructing a measure that on the face of it seems simple and straightforward — there is an additional risk of misclassifying the undernourished.

\section{Calorie Thresholds, Wealth and Food Prices}

Here an attempt is made to analyse calorie thresholds with India's NSS household data for 1993 and 2004. As the sample design is identical between these two rounds of the NSS, the results are comparable. The analysis is carried out separately for the rural and urban samples, 
as consumption patterns differ considerably (Gaiha et al. 2010). The calorie conversion was done using Gopalan et al. (1971) nutrient-food ratios. The food commodity classification used is sufficiently disaggregated for analysing switches from largely cereal to more diversified diets. ${ }^{11}$ Appropriately weighted food prices at the PSU level were constructed by us.

\section{(a) Lowess Results}

Following Jensen and Miller (2011), we first experiment with Lowess in which the dependent variable is the share of calories from cereals (cheapest and largest source of calories in India) and the right side variable, wealth of a household per capita, is approximated by monthly per capita expenditure (on 2004 prices). A logarithmic transformation of this variable is used. ${ }^{12}$

Let us first consider the results for rural India in 1993 and 2004. Figures 5 and 7 illustrate the Lowess results for rural India for 1993 and 2004. In 1993, The calorie share threshold occurs at 0.80 and the corresponding MPCE is Rs. 200.3. Counting those above the threshold (below and above the expenditure threshold), the proportion of undernourished works out to about a quarter of the rural population, which is below that under the calorie cut-off of 1800 per capita per day. As argued earlier, this estimate of the undernourished lumps together those with incomes below and well above the income threshold. The exclusion of those below the calorie and income thresholds (about 1.2 per cent) seems contentious, if not somewhat arbitrary.

In striking contrast to our analysis with fixed calorie norms which shows a sharp rise in the proportion of undernourished in rural India during 1993-2004, the Lowess results show a substantial reduction, from 27 per cent to 16 per cent. While the calorie threshold is the same (0.80) and the corresponding income is Rs. 244.7, much of the reduction is due to a sharp drop in the proportion of those above the threshold and the corresponding expenditure/ income. Further, there is also an increase in the proportion of those below the calorie and expenditure thresholds.

\footnotetext{
${ }^{11}$ Nine commodities are distinguished, comprising cereals, milk and milk products, vanaspati oil, sugar, eggs, meat/fish and poultry, pulses/nuts/dry fruits, fruits and vegetables. For details of their calorie content, see Gaiha et al. (2010).

12 Briefly, Lowess is used for locally weighted scatterplot smoothing. The smoothed values are obtained by running a regression of yvar on xvar using only the data $\left(\mathrm{x}_{\mathrm{i}}, \mathrm{y}_{\mathrm{i}}\right)$ and a small amount of the data near this point. The regression is weighted so that the central point $\left(\mathrm{x}_{\mathrm{i}}, \mathrm{y}_{\mathrm{i}}\right)$ gets the highest weight and points that are farther away (based on the distance $\left|x_{f}-x_{l}\right|$ ) receive less weight. The estimated regression line is then used to predict the smoothed value of $\hat{y}_{i}$ for $y_{i}$ only. This procedure is repeated to obtain the remaining smoothed values. Thus a separate weighted regression is performed for every point in the data. For a more detailed but intuitive exposition, see Deaton (1995).
} 
Figure 6: Distribution of Calories from Cereals for Rural India (1993)

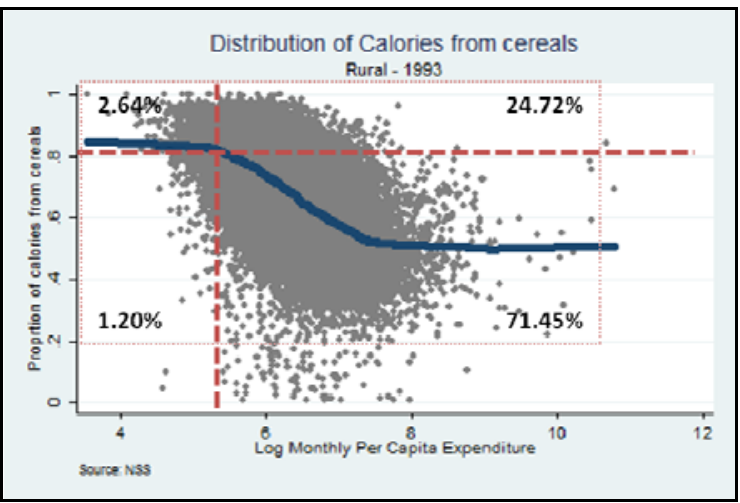

Figure 8: Distribution of Calories from Cereals for Urban India (1993)

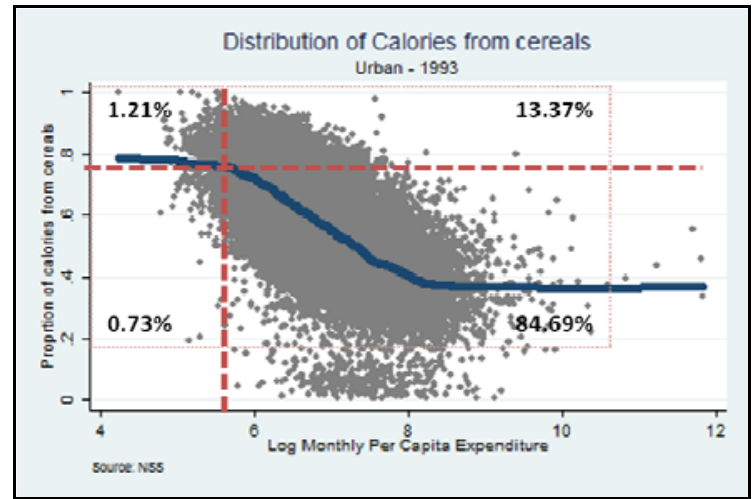

Figure 7: Distribution of Calories from Cereals for Rural India (2004)

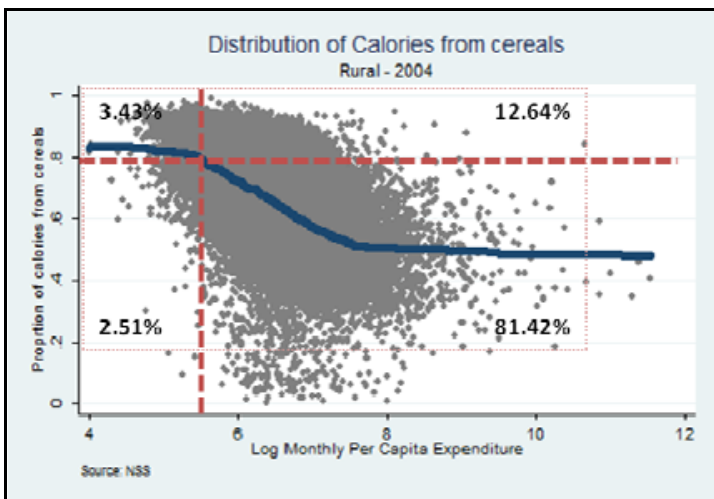

Figure 9: Distribution of Calories from Cereals for Urban India (2004)

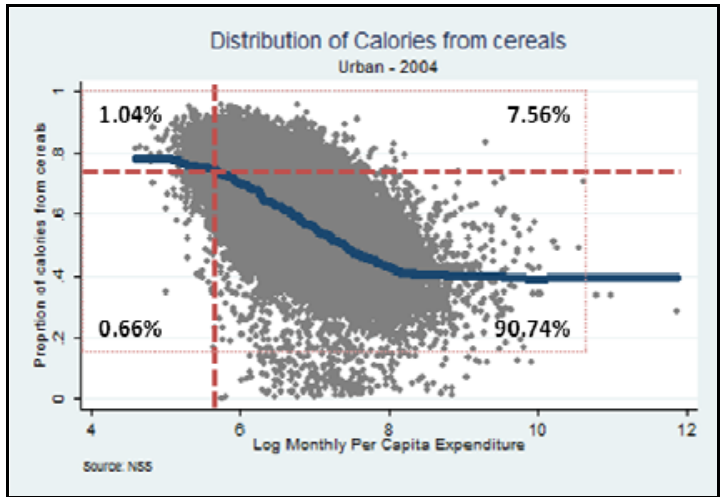

Let us now turn to the results for urban India. Figures 8 and 9 illustrate the Lowess results for urban India for 1993 and 2004. The calorie threshold in urban India in 1993 is lower than that in rural India but the expenditure corresponding to the former is slightly higher. However, the proportion of undernourished is a little over half of that for rural India. The majority of the former are those with calorie shares higher than the threshold and expenditures higher than the income threshold. There is a reduction in the proportion of undernourished (from 15 per cent to 9 per cent), due to a sharp reduction in the proportion of those above the calorie threshold and above the expenditure cut-off. This contrasts with the sharp increase in the proportion of undernourished with the calorie cut-off of 2100 (the proportion rises from about 58 per cent to about 64 per cent).

Additional insights into changing distributions of calorie shares are obtained from the kernel density ${ }^{13}$ graphs in Figure 10 (Rural India) and Figure 11 (Urban India). As shown, the pdf of

\footnotetext{
${ }^{13}$ We have used the Epanechnikov kernel function. For an intuitive exposition, see Deaton (1995).
} 
calorie share of cereals shifted to the left - given the cutoff of .80 for rural India, and a cutoff of .75 for urban India, respectively, consistent with the reduction in the proportion of undernourished.

Figure 10: Kernel Density of Calorie Share of Cereals in Rural India, 1993-2004

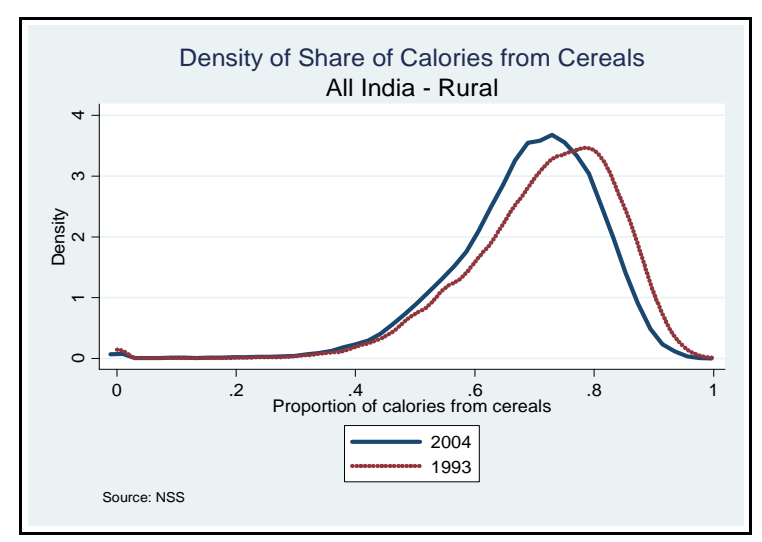

Figure 11: Kernel Density of Calorie Share of Cereals in Urban India, 1993-2004.

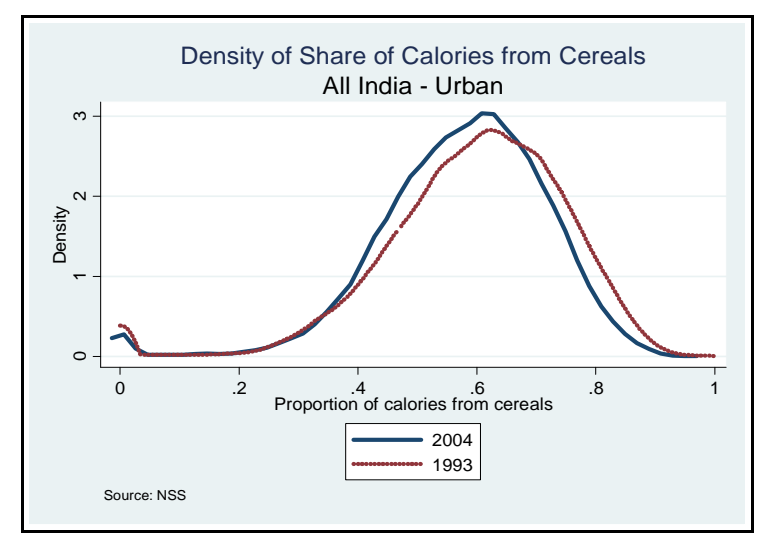

In sum, the estimates of undernourished are lower than those obtained using fixed calorie norms for rural and urban India. Besides, while Lowess results point to a reduction in the proportion of undernourished over the period 1993-2004 - especially in rural India - a sharp rise is observed using fixed calorie cut-off points. Finally, not just lumping together of undernourished below and above the expenditure threshold but also failure to classify those below both the expenditure and calorie share thresholds weaken the intuitive appeal of the measure of undernutrition proposed by Jensen and Miller (2011).

\section{(b) Calorie Share, Expenditure and Prices}

So far the focus was on the relationship between calorie share of cereals and monthly per capita expenditure (MPCE). Following our distillation of two important contributions establishing the important role of food prices in inducing substitutions between different sources of calories (e.g. cereals and cassava), we explore with the NSS data how sensitive calorie shares are to food prices and whether a calorie threshold exists and, in case it does, whether estimates of undernourished change substantially. ${ }^{14}$ This analysis is carried out separately for the four NSS samples: rural 1993, rural 2004, urban 1993 and urban 2004.

\footnotetext{
${ }^{14}$ For a recent analysis of dietary transition in India driven by growth of income and urbanisation, and food prices, see Kaicker et al. (2011).
} 


\section{(i) Specification}

We use the following specification for our analysis:

$$
C_{t}=\alpha+\beta_{1}\left(\ln Y_{t}\right)+\beta_{2}\left(\ln Y_{t}\right)^{2}+(\ln P) \cdot \gamma+\delta_{1}(H H)+\delta_{2}(A)+S \cdot \rho+C \cdot \varphi+\varepsilon_{t}
$$

where the dependent variable is the proportion of calories obtained from cereals by the $i^{\text {th }}$ household, $Y_{i}$ denotes per capita monthly expenditure, $\boldsymbol{P}$ denotes a vector of food prices, $E H$ denotes household size, $\boldsymbol{A}$ is proportion of adult males in the household, $\boldsymbol{S}$ is a vector of state dummy variables (with Jammu and Kashmir as the omitted state), $\boldsymbol{C}$ is a vector of caste dummy variables (with Scheduled Castes as the omitted group), and $\varepsilon_{i}$ is the iid error term.

In order to allow for differences in calorie share responses to expenditure and food prices, among other explanatory variables, we have split each sample into four sub-samples comprising: acutely poor, moderately poor, moderately affluent and affluent. These categories are defined in terms of the poverty cut-off points. Those with MPCE $<0.75$ of the poverty cut-off point are classified as acutely poor, and the remaining poor as moderately poor; and those with MPCE $>1.25$ of the poverty cut-off point are classified as moderately affluent and all others above this cut-off point as affluent. ${ }^{15}$ The cutoff points (at 2004 prices) are given below in Table 3:

Table 3: Poverty Cut-Off Points

\begin{tabular}{|l|l|l|l|l|}
\hline MPCE & Acutely Poor & Moderately Poor & Moderately Affluent & Affluent \\
\hline Rural & $<$ Rs. 268.5 & Rs. 268.5-358.0 & Rs. 358.0-447.5 & > Rs. 447.5 \\
\hline Urban & $<$ Rs. 405.3 & Rs. 405.3-540.4 & Rs. 540.4-675.5 & > Rs. 675.5 \\
\hline
\end{tabular}

The robust regression results are discussed below.

\footnotetext{
${ }^{15}$ We follow Timmer (1981) here and acknowledge his advice on splitting the sample by expenditure group.
} 


\section{Results}

\section{Rural India}

Let us first consider the results with the rural India sample for 1993, given in Table 4. Among the acutely poor, the calorie share varies with expenditure and inversely with its square. ${ }^{16}$ Demographic variables also influence the calorie share - it rises with household size and proportion of adults. The Scheduled Tribes (STs) and Others have lower calorie shares than the Scheduled Castes (SCs). Controlling for these effects, food prices have significant effects on the calorie share: the higher the price of vegetables, the higher is the share of calories, while the lower the price of pulses/nuts/ others, the lower is this share. Somewhat surprisingly, this share is not influenced by the price of cereals. Although just two price effects are significant, they point to substitutes (vegetables) and complements (pulses/nuts/others) in the diets of the acutely poor.

Somewhat surprisingly, among the moderately poor, while the calorie share varies positively with expenditure and inversely with its square, the coefficients are not significant. The share also varies positively with proportion of adults. Among the caste dummies, Others has a significant negative coefficient, implying that the calorie share is lower among them relative to the SCs while that of the STs is negative but (weakly) significant. The price effects are more varied relative to acutely poor. The calorie share varies positively with cereal price, as also with prices of vegetables and of meat/fish/poultry, and negatively with price of pulses/nuts/others. Whether cereals have elements of a Giffen good needs further investigation - especially because inferior cereals are combined with wheat and rice. As among the acutely poor, there is further evidence of substitutes (vegetables, and meat/fish/poultry) and complements (pulses/nuts/others).

Among the moderately affluent too, the coefficients of expenditure and its square are not significant while the signs are reversed. Both demographic variables have significant effects: size and proportion of adults are associated with higher calorie shares. Others have significantly lower calorie shares relative to the SCs. The price effects are varied, with price of cereals positively related to the calorie share, as also price of vegetables, and negatively to price of pulses/nuts/others, further confirming sensitiveness of this share to food prices.

\footnotetext{
${ }^{16}$ For expositional convenience, and given a monotonic relationship between expenditure and its logarithmic transformation, expenditure is synonymous with its log.
} 
Table 4: Regression Results: Rural India (1993)

\begin{tabular}{|c|c|c|c|c|c|c|c|c|c|c|c|c|}
\hline $\begin{array}{l}\text { No. of } \\
\text { Observations }\end{array}$ & \multicolumn{3}{|c|}{2878} & \multicolumn{3}{|c|}{5843} & \multicolumn{3}{|c|}{6817} & \multicolumn{3}{|c|}{22389} \\
\hline F-Value & \multicolumn{3}{|c|}{63.22} & \multicolumn{3}{|c|}{59.60} & \multicolumn{3}{|c|}{74.18} & \multicolumn{3}{|c|}{494.18} \\
\hline \multirow[t]{2}{*}{ Prob. > F } & \multicolumn{3}{|c|}{0.000} & \multicolumn{3}{|c|}{0.000} & \multicolumn{3}{|c|}{0.000} & \multicolumn{3}{|c|}{0.000} \\
\hline & \multicolumn{3}{|c|}{ Acutely Poor } & \multicolumn{3}{|c|}{ Moderately Poor } & \multicolumn{3}{|c|}{ Moderately Affluent } & \multicolumn{3}{|c|}{ Affluent } \\
\hline Log MPCE & 0.745 & $(7.55)$ & $* * *$ & 2.083 & $(1.24)$ & - & -2.362 & $(-0.85)$ & - & -0.592 & $(-27.58)$ & $* * *$ \\
\hline$(\log M P C E)^{\wedge} 2$ & -0.080 & $(-8.25)$ & $* * *$ & -0.189 & $(-1.3)$ & - & 0.186 & $(0.8)$ & - & 0.034 & $(22.43)$ & $* * *$ \\
\hline $\begin{array}{l}\text { Log - Price of } \\
\text { Milk \& Milk } \\
\text { Products }\end{array}$ & 0.001 & $(0.24)$ & - & -0.001 & $(-0.58)$ & - & 0.000 & $(-0.09)$ & - & -0.002 & $(-1.46)$ & - \\
\hline $\begin{array}{l}\text { Log - Price of } \\
\text { Vanaspati Oil }\end{array}$ & -0.014 & $(-0.91)$ & - & -0.011 & $(-1.04)$ & - & -0.010 & $(-0.97)$ & - & -0.012 & $(-1.71)$ & $*$ \\
\hline $\begin{array}{l}\text { Log - Price of } \\
\text { Sugar }\end{array}$ & -0.012 & $(-1.1)$ & - & -0.011 & $(-1.45)$ & - & -0.009 & $(-1.32)$ & - & 0.001 & $(0.24)$ & - \\
\hline $\begin{array}{l}\text { Log - Price of } \\
\text { Eggs }\end{array}$ & 0.001 & $(0.31)$ & - & -0.002 & $(-0.68)$ & - & -0.003 & $(-1.41)$ & - & 0.007 & $(4.62)$ & $* * *$ \\
\hline $\begin{array}{l}\text { Log - Price of } \\
\text { Meat/Fish/Poultry }\end{array}$ & 0.003 & $(0.9)$ & - & 0.006 & (2.48) & $* *$ & -0.003 & $(-1.11)$ & - & -0.002 & $(-1.06)$ & - \\
\hline $\begin{array}{l}\text { Log - Price of } \\
\text { Pulses/Nuts/Others }\end{array}$ & -0.003 & $(-1.94)$ & $*$ & -0.005 & $(-4.19)$ & $* * *$ & -0.005 & $(-4.38)$ & $* * *$ & -0.006 & $(-7.44)$ & $* * *$ \\
\hline $\begin{array}{l}\text { Log - Price of } \\
\text { Fruits }\end{array}$ & 0.000 & $(0.2)$ & - & 0.001 & $(0.49)$ & - & 0.002 & (1.39) & - & 0.002 & $(1.81)$ & $*$ \\
\hline $\begin{array}{l}\text { Log - Price of } \\
\text { Vegetables }\end{array}$ & 0.018 & $(3.16)$ & $* * *$ & 0.010 & $(2.6)$ & $* * *$ & 0.011 & $(2.82)$ & $* * *$ & 0.011 & $(4.52)$ & $* * *$ \\
\hline $\begin{array}{l}\text { Log - Price of } \\
\text { Cereals }\end{array}$ & 0.007 & (1.13) & - & 0.010 & (2.03) & $* *$ & 0.018 & (3.57) & $* * *$ & 0.003 & $(0.67)$ & - \\
\hline Household Size & 0.002 & $(2.81)$ & $* * *$ & 0.000 & $(0.94)$ & - & 0.001 & $(2.28)$ & $* *$ & 0.003 & (10.95) & $* * *$ \\
\hline $\begin{array}{l}\text { Proportion of } \\
\text { Adult males in the } \\
\text { Household }\end{array}$ & 0.040 & $(4.68)$ & $* * *$ & 0.033 & (5.87) & $* * *$ & 0.035 & $(6.91)$ & $* * *$ & 0.024 & $(8.78)$ & $* * *$ \\
\hline $\begin{array}{l}\text { Caste Dummy } \\
\text { (ST) }\end{array}$ & -0.010 & $(-2.32)$ & $* *$ & -0.005 & $(-1.46)$ & - & -0.004 & $(-1.24)$ & - & 0.005 & $(1.95)$ & $*$ \\
\hline $\begin{array}{l}\text { Caste Dummy } \\
\text { (Others) }\end{array}$ & -0.019 & $(-4.77)$ & $* * *$ & -0.018 & $(-6.29)$ & $* * *$ & -0.021 & $(-7.18)$ & $* * *$ & -0.025 & $(-10.8)$ & $* * *$ \\
\hline Constant & -0.854 & $(-3.25)$ & - & -4.875 & $(-1.01)$ & - & 8.273 & $(0.99)$ & - & 3.048 & (38.38) & - \\
\hline \multicolumn{13}{|c|}{$* * *, * *$ and $*$ refer to significance at the $1 \%, 5 \%$ and $10 \%$ level, respectively. } \\
\hline \multicolumn{13}{|c|}{ State Dummies are omitted and details will be furnished on request } \\
\hline \multicolumn{13}{|c|}{$\begin{array}{l}\text { Threshold Value: } \\
\text { MPCE: Rs. } 105.4 \\
\text { Proportion of Calories from Cereals: } 0.86\end{array}$} \\
\hline
\end{tabular}

Among the affluent and, in striking contrast to the previous two groups, expenditure has a significant negative effect while its square has a positive effect. Both demographic variables (household size and proportion of adults) have significant positive effects. The STs have a higher calorie share while Others have a lower share relative to the SCs. Both prices of vanaspati oils and pulses/nuts and others have significant negative coefficients, implying that they are complements. Prices of eggs, fruits and vegetables, by contrast, are positive, implying that they are substitutes. So, among the affluent too, food prices influence calories from cereals. 
Let us now turn to the results from the rural sample for 2004 (Table 5). There are some changes - especially in the food price effects.

Table 5: Regression Results: Rural India (2004)

\begin{tabular}{|c|c|c|c|c|c|c|c|c|c|c|c|c|}
\hline $\begin{array}{l}\text { No. of } \\
\text { Observations } \\
\end{array}$ & \multicolumn{3}{|c|}{2486} & \multicolumn{3}{|c|}{6171} & \multicolumn{3}{|c|}{8144} & \multicolumn{3}{|c|}{37240} \\
\hline F-Value & \multicolumn{3}{|c|}{108.59} & \multicolumn{3}{|c|}{77.96} & \multicolumn{3}{|c|}{100.02} & \multicolumn{3}{|c|}{962.90} \\
\hline \multirow[t]{2}{*}{ Prob. > F } & \multicolumn{3}{|c|}{0.000} & \multicolumn{3}{|c|}{0.000} & \multicolumn{3}{|c|}{0.000} & \multicolumn{3}{|c|}{0.000} \\
\hline & \multicolumn{3}{|c|}{ Acutely Poor } & \multicolumn{3}{|c|}{ Moderately Poor } & \multicolumn{3}{|c|}{ Moderately Affluent } & \multicolumn{3}{|c|}{ Affluent } \\
\hline Log MPCE & 3.216 & (37.29) & $* * *$ & 2.774 & (1.9) & * & 1.938 & $(0.84)$ & - & -0.472 & $(-38.79)$ & $* * *$ \\
\hline$(\log M P C E)^{\wedge} 2$ & -0.309 & $(-36.27)$ & $* * *$ & -0.250 & $(-1.96)$ & $* *$ & -0.173 & $(-0.9)$ & - & 0.026 & (30.71) & $* * *$ \\
\hline $\begin{array}{l}\text { Log - Price of } \\
\text { Milk \& Milk } \\
\text { Products }\end{array}$ & -0.004 & $(-2.23)$ & $* *$ & -0.002 & $(-1.01)$ & - & -0.001 & $(-0.68)$ & - & 0.008 & $(8.75)$ & $* * *$ \\
\hline $\begin{array}{l}\text { Log - Price of } \\
\text { Vanaspati Oil }\end{array}$ & 0.029 & (2.09) & $* *$ & 0.035 & $(3.45)$ & $* * *$ & 0.036 & $(4.07)$ & $* * *$ & 0.020 & $(4.92)$ & $* * *$ \\
\hline $\begin{array}{l}\text { Log - Price of } \\
\text { Sugar }\end{array}$ & -0.014 & $(-1.15)$ & - & -0.005 & $(-0.63)$ & - & -0.007 & $(-1.04)$ & - & -0.032 & $(-9.09)$ & $* * *$ \\
\hline $\begin{array}{l}\text { Log - Price of } \\
\text { Eggs }\end{array}$ & 0.009 & $(1.53)$ & - & 0.006 & $(1.81)$ & $*$ & 0.005 & $(1.45)$ & - & -0.003 & $(-1.71)$ & $*$ \\
\hline $\begin{array}{l}\text { Log - Price of } \\
\text { Meat/Fish/Poultry }\end{array}$ & 0.004 & $(0.99)$ & - & -0.001 & $(-0.33)$ & - & 0.004 & $(1.54)$ & - & 0.004 & $(2.54)$ & $* *$ \\
\hline $\begin{array}{l}\text { Log - Price of } \\
\text { Pulses/Nuts/Others }\end{array}$ & -0.003 & $(-1.48)$ & - & -0.002 & $(-1.46)$ & - & -0.004 & $(-3.29)$ & $* * *$ & 0.000 & $(-0.5)$ & - \\
\hline $\begin{array}{l}\text { Log - Price of } \\
\text { Fruits }\end{array}$ & 0.012 & (5.19) & $* * *$ & 0.009 & (5.67) & $* * *$ & 0.010 & (6.58) & $* * *$ & 0.009 & (10.05) & $* * *$ \\
\hline $\begin{array}{l}\text { Log - Price of } \\
\text { Vegetables }\end{array}$ & 0.011 & $(1.95)$ & $*$ & 0.018 & $(4.63)$ & $* * *$ & 0.015 & $(4.36)$ & $* * *$ & 0.004 & (2.19) & $* *$ \\
\hline $\begin{array}{l}\text { Log - Price of } \\
\text { Cereals }\end{array}$ & -0.009 & $(-1.02)$ & - & -0.001 & $(-0.17)$ & - & -0.006 & $(-1.2)$ & - & -0.033 & $(-11.45)$ & $* * *$ \\
\hline Household Size & 0.001 & (1.89) & $*$ & 0.001 & (2.88) & $* * *$ & 0.001 & (2.96) & $* * *$ & 0.003 & $(17.06)$ & $* * *$ \\
\hline $\begin{array}{l}\text { Proportion of } \\
\text { Adult males in the } \\
\text { Household }\end{array}$ & 0.019 & $(2.48)$ & $* *$ & 0.025 & $(5.02)$ & $* * *$ & 0.025 & (5.78) & $* * *$ & 0.019 & $(9.82)$ & $* * *$ \\
\hline $\begin{array}{l}\text { Caste Dummy } \\
\text { (ST) }\end{array}$ & -0.010 & $(-2.68)$ & $* * *$ & -0.010 & $(-3.76)$ & $* * *$ & -0.004 & $(-1.6)$ & - & -0.003 & $(-1.86)$ & $*$ \\
\hline $\begin{array}{l}\text { Caste Dummy } \\
\text { (Others) }\end{array}$ & -0.019 & $(-5.65)$ & $* * *$ & -0.022 & $(-9.26)$ & $* * *$ & -0.016 & $(-6.79)$ & $* * *$ & -0.021 & $(-14.35)$ & $* * *$ \\
\hline Constant & -7.800 & $(-33.31)$ & - & -7.176 & $(-1.71)$ & - & -4.897 & $(-0.71)$ & - & 2.653 & (56.16) & - \\
\hline \multicolumn{13}{|c|}{$* * *, * *$ and $*$ refer to significance at the $1 \%, 5 \%$ and $10 \%$ level, respectively. } \\
\hline \multicolumn{13}{|c|}{ State Dummies are omitted and details will be furnished on request } \\
\hline \multicolumn{13}{|c|}{$\begin{array}{l}\text { Threshold Value: } \\
\text { MPCE: Rs. } 181.2 \\
\text { Proportion of Calories from Cereals: } 0.83\end{array}$} \\
\hline
\end{tabular}

Among the acutely poor, as in 1993, expenditure has a positive effect and its square has a negative effect on the calorie share. Both demographic variables (household size and proportion of adults) have significant positive effects. Both caste dummies (STs and others) have significant negative coefficients, implying lower calorie share than among the SCs. 
Food price effects are more varied than in 1993: while cereal price ceases to have a significant effect, that of milk and milk products has a negative effect (complement); price of pulses/nuts/others has a negative coefficient that is (weakly) significant; by contrast, prices of vegetables, vanaspati oil and fruits have positive effects on calorie share (substitutes); and, finally, price of eggs has a positive coefficient which is (weakly) significant. Thus, calorie share is influenced not just by expenditure, demographic and caste characteristics but also by food prices.

Among the moderately poor, unlike in 1993, expenditure has a significant positive effect while its square has a significant negative effect. Both demographic variables (household size and proportion of adults) have positive effects on the calorie share. Both caste variables (STs and others) have significant negative coefficients, implying lower calorie shares relative to the SCs. Food price effects are more varied: while cereal price ceases to have a significant effect, prices of vanapati oil, eggs, fruits and vegetables have significant positive effects (substitutes); although price of pulses/nuts/others has a negative coefficient, it is (weakly) significant.

Among the moderately affluent, as in 1993, expenditure and its square do not possess significant coefficients. Demographic characteristics (household size and proportion of adults) tend to raise the calorie share while caste characteristics (STs and Others) tend to lower it relative to the SCs. Food price effects are varied, as in 1993, but with a few differences. Price of cereals ceases to have a significant effect; and price of vanaspati oil has a significant positive effect. Price of pulses/nuts/others has a negative effect (complement), as in 1993. Prices of fruits and vegetables have positive effects while that of meat/fish/poultry has a (weakly) significant positive effect on the calorie share.

Among the affluent, expenditure has a negative effect while its square has a positive effect. Both demographic variables (household size and proportion of adults) tend to raise the calorie share while the caste variables (STs and Others) are associated with lower shares relative to the SCs. While prices of cereals, sugar and eggs lower the calorie share, those of milk and milk products, vanaspati oil, meat/fish/poultry, fruits, and vegetables raise this share. 


\section{Urban India}

The sample for urban India in 1993 yields results that are in some respects strikingly different from the rural results - especially the food price effects (Table 6).

Among the acutely poor in urban India in 1993, both expenditure and its square have significant effects - positive and negative, respectively — on the calorie share. Proportion of adults has a significant positive effect while the caste dummies (STs and Others) have negative effects (relative to the SCs). Three food price effects are significantly negative milk and milk products, vanaspati oil and pulses/nuts/others — pointing to their complementarity to cereals. Thus, the calorie share is sensitive to expenditure, demographic and caste characteristics and food prices.

Among the moderately poor, expenditure and its square do not have significant effects. Proportion of adults has a positive effect while Others have lower calorie shares than the SCs. The price effects are more varied than among the acutely poor. Prices of vanaspati oil, pulses/nuts/others and fruits (weakly significant) and vegetables are negatively significant. Price of cereals has a positive effect as also price of eggs. These results further confirm the role of food prices at low incomes in determining the calorie share.

Among the moderately affluent too and just as intriguing is the lack of significance of the effects of expenditure and its square. Demographic effects are positive, while among Others calorie shares are lower than among the SCs. The price effects are varied. Cereal price has a positive effect, while prices of vanaspati oil, meat/fish/poultry, pulses/nuts/others and vegetables have negative effects. Not so surprising is the conclusion that the diets of the moderately affluent (as also the calorie share) are influenced by food prices.

Among the affluent, by contrast, expenditure and its square have significant effects (negative and positive, respectively). Demographic effects are significant too while the caste dummy for Others has a significant negative effect on the calorie share. Price effects are far more varied than among the moderately affluent. Price of cereals has a negative effect, as also those of vanaspati oil, pulses/nuts/others and vegetables. 
Table 6: Regression Results: Urban India (1993)

\begin{tabular}{|c|c|c|c|c|c|c|c|c|c|c|c|c|}
\hline $\begin{array}{l}\text { No. of } \\
\text { Observations }\end{array}$ & \multicolumn{3}{|c|}{2601} & \multicolumn{3}{|c|}{4399} & \multicolumn{3}{|c|}{4630} & \multicolumn{3}{|c|}{23573} \\
\hline F-Value & \multicolumn{3}{|c|}{36.77} & \multicolumn{3}{|c|}{42.77} & \multicolumn{3}{|c|}{46.51} & \multicolumn{3}{|c|}{558.52} \\
\hline \multirow[t]{2}{*}{ Prob. > F } & \multicolumn{3}{|c|}{0.000} & \multicolumn{3}{|c|}{0.000} & \multicolumn{3}{|c|}{0.000} & \multicolumn{3}{|c|}{0.000} \\
\hline & \multicolumn{3}{|c|}{ Acutely Poor } & \multicolumn{3}{|c|}{ Moderately Poor } & \multicolumn{3}{|c|}{ Moderately Affluent } & \multicolumn{3}{|c|}{ Affluent } \\
\hline Log MPCE & 1.414 & $(13.8)$ & $* * *$ & 0.367 & $(0.16)$ & - & 1.752 & $(0.43)$ & - & -0.539 & $(-27.81)$ & $* * *$ \\
\hline$(\log M P C E)^{\wedge} 2$ & -0.132 & $(-14.12)$ & $* * *$ & -0.042 & $(-0.22)$ & - & -0.149 & $(-0.47)$ & - & 0.028 & (21.59) & $* * *$ \\
\hline $\begin{array}{l}\text { Log - Price of } \\
\text { Milk \& Milk } \\
\text { Products }\end{array}$ & -0.015 & $(-2.82)$ & $* * *$ & -0.001 & $(-0.21)$ & - & 0.002 & $(0.53)$ & - & 0.020 & $(10.04)$ & $* * *$ \\
\hline $\begin{array}{l}\text { Log - Price of } \\
\text { Vanaspati Oil } \\
\end{array}$ & -0.094 & $(-4.67)$ & $* * *$ & -0.059 & $(-3.86)$ & $* * *$ & -0.029 & $(-1.92)$ & $*$ & -0.060 & $(-8.32)$ & $* * *$ \\
\hline $\begin{array}{l}\text { Log - Price of } \\
\text { Sugar }\end{array}$ & -0.004 & $(-0.28)$ & - & -0.012 & $(-1.12)$ & - & 0.001 & $(0.05)$ & - & 0.000 & $(-0.09)$ & - \\
\hline $\begin{array}{l}\text { Log - Price of } \\
\text { Eggs }\end{array}$ & 0.003 & $(0.62)$ & - & 0.010 & $(2.29)$ & $* *$ & 0.004 & $(0.79)$ & - & 0.008 & (3.37) & $* * *$ \\
\hline $\begin{array}{l}\text { Log - Price of } \\
\text { Meat/Fish/Poultry }\end{array}$ & 0.002 & $(0.55)$ & - & -0.002 & $(-0.58)$ & - & -0.007 & $(-1.94)$ & $*$ & 0.010 & $(4.35)$ & $* * *$ \\
\hline $\begin{array}{l}\text { Log - Price of } \\
\text { Pulses/Nuts/Others }\end{array}$ & -0.012 & $(-4.82)$ & $* * *$ & -0.013 & $(-6.82)$ & $* * *$ & -0.018 & $(-9.25)$ & $* * *$ & -0.018 & $(-16.49)$ & $* * *$ \\
\hline $\begin{array}{l}\text { Log - Price of } \\
\text { Fruits }\end{array}$ & -0.002 & $(-0.49)$ & - & -0.005 & $(-1.59)$ & - & 0.000 & $(0.06)$ & - & -0.002 & $(-1.03)$ & - \\
\hline $\begin{array}{l}\text { Log - Price of } \\
\text { Vegetables }\end{array}$ & 0.006 & $(0.79)$ & - & -0.013 & $(-2.36)$ & $* *$ & -0.010 & $(-1.75)$ & $*$ & -0.007 & $(-2.46)$ & $* *$ \\
\hline $\begin{array}{l}\text { Log - Price of } \\
\text { Cereals }\end{array}$ & 0.009 & $(0.74)$ & - & 0.023 & $(2.42)$ & $* *$ & 0.023 & $(2.2)$ & $* *$ & -0.043 & $(-8.8)$ & $* * *$ \\
\hline Household Size & 0.000 & $(0.5)$ & - & 0.000 & $(-0.16)$ & - & 0.001 & $(2.41)$ & $* *$ & 0.003 & $(9.72)$ & $* * *$ \\
\hline $\begin{array}{l}\text { Proportion of } \\
\text { Adult males in the } \\
\text { Household }\end{array}$ & 0.045 & $(5.05)$ & $* * *$ & 0.033 & $(4.91)$ & $* * *$ & 0.047 & $(7.52)$ & $* * *$ & 0.052 & $(21.7)$ & $* * *$ \\
\hline $\begin{array}{l}\text { Caste Dummy } \\
\text { (ST) }\end{array}$ & -0.026 & $(-3.2)$ & $* * *$ & 0.005 & $(0.76)$ & - & -0.012 & $(-1.76)$ & $*$ & 0.006 & $(1.45)$ & - \\
\hline $\begin{array}{l}\text { Caste Dummy } \\
\text { (Others) }\end{array}$ & -0.046 & $(-6.05)$ & $* * *$ & -0.023 & $(-3.53)$ & $* * *$ & -0.037 & $(-6.01)$ & $* * *$ & -0.030 & $(-9.03)$ & $* * *$ \\
\hline Constant & -2.629 & $(-8.85)$ & - & 0.234 & $(0.03)$ & - & -4.327 & $(-0.33)$ & - & 3.186 & (41.66) & - \\
\hline \multicolumn{13}{|c|}{$* * *, * *$ and $*$ refer to significance at the $1 \%, 5 \%$ and $10 \%$ level, respectively. } \\
\hline \multicolumn{13}{|c|}{ State Dummies are omitted and details will be furnished on request. } \\
\hline \multicolumn{13}{|c|}{$\begin{array}{l}\text { Threshold Value: } \\
\text { MPCE: Rs. } 209.5 \\
\text { Proportion of Calories from Cereals: } 0.78\end{array}$} \\
\hline
\end{tabular}

Let us now discuss the results for urban India in 2004 given in Table 7.

Among the acutely poor, expenditure and its square are significant in determining the calorie share. Proportion of adults has a positive effect while both caste dummies have negative effects (relative to the SCs). Both prices of cereals and of pulses/nuts/others lower this share while those of vanaspati oil, eggs, and fruits raise it. Food prices thus matter along with expenditure and other explanatory variables. 
Table 7: Regression Results: Urban India (2004)

\begin{tabular}{|c|c|c|c|c|c|c|c|c|c|c|c|c|}
\hline $\begin{array}{l}\text { No. of } \\
\text { Observations }\end{array}$ & \multicolumn{3}{|c|}{4139} & \multicolumn{3}{|c|}{5674} & \multicolumn{3}{|c|}{4604} & \multicolumn{3}{|c|}{22194} \\
\hline F-Value & \multicolumn{3}{|c|}{77.05} & \multicolumn{3}{|c|}{107.02} & \multicolumn{3}{|c|}{69.69} & \multicolumn{3}{|c|}{543.19} \\
\hline \multirow[t]{2}{*}{ Prob. > F } & \multicolumn{3}{|c|}{0.000} & \multicolumn{3}{|c|}{0.000} & \multicolumn{3}{|c|}{0.000} & \multicolumn{3}{|c|}{0.000} \\
\hline & \multicolumn{3}{|c|}{ Acutely Poor } & \multicolumn{3}{|c|}{ Moderately Poor } & \multicolumn{3}{|c|}{ Moderately Affluent } & \multicolumn{3}{|c|}{ Affluent } \\
\hline Log MPCE & 0.750 & (19.95) & $* * *$ & -2.847 & $(-1.58)$ & - & 3.840 & (1.05) & - & -0.528 & $(-28.55)$ & $* * *$ \\
\hline$(\log M P C E)^{\wedge} 2$ & -0.075 & $(-20.98)$ & $* * *$ & 0.221 & (1.51) & - & -0.311 & $(-1.09)$ & - & 0.028 & (22.82) & $* * *$ \\
\hline $\begin{array}{l}\text { Log - Price of } \\
\text { Milk \& Milk } \\
\text { Products }\end{array}$ & 0.002 & $(0.58)$ & - & 0.001 & $(0.51)$ & - & 0.006 & $(1.75)$ & * & 0.004 & (2.59) & $* * *$ \\
\hline $\begin{array}{l}\text { Log - Price of } \\
\text { Vanaspati Oil }\end{array}$ & 0.068 & (5.25) & $* * *$ & 0.029 & (3.07) & $* * *$ & 0.006 & $(0.59)$ & - & 0.014 & $(2.42)$ & $* *$ \\
\hline $\begin{array}{l}\text { Log - Price of } \\
\text { Sugar }\end{array}$ & -0.014 & $(-1.16)$ & - & -0.034 & $(-3.85)$ & $* * *$ & -0.060 & $(-6.3)$ & $* * *$ & -0.046 & $(-9.3)$ & $* * *$ \\
\hline $\begin{array}{l}\text { Log - Price of } \\
\text { Eggs }\end{array}$ & 0.017 & (2.49) & $* *$ & 0.016 & (3.38) & $* * *$ & 0.013 & (2.33) & $* *$ & 0.010 & (3.13) & $* * *$ \\
\hline $\begin{array}{l}\text { Log - Price of } \\
\text { Meat/Fish/Poultry }\end{array}$ & 0.005 & $(1.37)$ & - & 0.003 & $(0.82)$ & - & 0.004 & $(1.02)$ & - & 0.012 & (5.43) & $* * *$ \\
\hline $\begin{array}{l}\text { Log - Price of } \\
\text { Pulses/Nuts/Others }\end{array}$ & -0.005 & $(-2.44)$ & $* *$ & -0.006 & $(-3.48)$ & $* * *$ & -0.008 & $(-3.91)$ & $* * *$ & 0.000 & $(-0.14)$ & - \\
\hline $\begin{array}{l}\text { Log - Price of } \\
\text { Fruits }\end{array}$ & 0.007 & (2.54) & $* *$ & 0.010 & (4.31) & $* * *$ & 0.005 & (1.73) & * & 0.002 & (1.49) & - \\
\hline $\begin{array}{l}\text { Log - Price of } \\
\text { Vegetables }\end{array}$ & 0.005 & $(0.83)$ & - & 0.008 & (1.76) & $*$ & 0.007 & (1.36) & - & -0.005 & $(-1.78)$ & $*$ \\
\hline $\begin{array}{l}\text { Log - Price of } \\
\text { Cereals }\end{array}$ & -0.054 & $(-6.99)$ & $* * *$ & -0.038 & $(-5.98)$ & $* * *$ & -0.033 & $(-4.37)$ & $* * *$ & -0.054 & $(-14.18)$ & $* * *$ \\
\hline Household Size & 0.000 & (1.1) & - & 0.001 & (3.43) & $* * *$ & 0.001 & (2.14) & $* *$ & 0.003 & (11.08) & $* * *$ \\
\hline $\begin{array}{l}\text { Proportion of } \\
\text { Adult males in the } \\
\text { Household }\end{array}$ & 0.026 & $(4.34)$ & $* * *$ & 0.038 & (7.78) & $* * *$ & 0.043 & (8.11) & $* * *$ & 0.026 & (11.41) & $* * *$ \\
\hline $\begin{array}{l}\text { Caste Dummy } \\
\text { (ST) }\end{array}$ & -0.008 & $(-1.65)$ & $*$ & -0.017 & $(-3.62)$ & $* * *$ & -0.007 & $(-1.24)$ & - & -0.017 & $(-5.17)$ & $* * *$ \\
\hline $\begin{array}{l}\text { Caste Dummy } \\
\text { (Others) }\end{array}$ & -0.021 & $(-4.83)$ & $* * *$ & -0.028 & $(-6.56)$ & $* * *$ & -0.022 & $(-4.18)$ & $* * *$ & -0.035 & $(-11.87)$ & $* * *$ \\
\hline Constant & -1.330 & $(-10.57)$ & - & 9.805 & $(1.77)$ & - & -11.056 & $(-0.94)$ & - & 3.026 & (40.67) & - \\
\hline \multicolumn{13}{|c|}{$* * *, * *$ and $*$ refer to significance at the $1 \%, 5 \%$ and $10 \%$ level, respectively. } \\
\hline \multicolumn{13}{|c|}{ State Dummies have been omitted in the above table and shall be available on request } \\
\hline $\begin{array}{l}\text { Threshold Value: } \\
\text { MPCE: Rs. 151.4 } \\
\text { Proportion of Calor }\end{array}$ & from $C$ & ls: 0.78 & & & & & & & & & & \\
\hline
\end{tabular}

Among the moderately poor, while expenditure has a (weakly) significant negative effect, its square has a (weakly) significant positive effect. Demographic variables have positive effects while caste variables have negative effects. Price effects matter too. Prices of sugar, pulses/nuts/others and cereals lower the calorie share while those of vanaspati oil, eggs, fruits, and vegetables raise this share.

Some results for the moderately affluent differ. For example, the expenditure effects are not significant. While both demographic variables have positive effects, only one caste variable 
(Others) has a significant negative effect. As in the case of the moderately poor, prices of sugar, pulses/nuts/others and cereals lower the calorie share. Prices of milk and milk products, eggs, and fruits, by contrast, have positive effects.

Among the affluent, expenditure has a negative effect while its square has a positive effect on the calorie share. Domographic variables have positive effects while caste variables have negative effects on this share. All food prices other than those of pulses/nuts/others, and fruits have significant effects. Prices of cereals, vegetables and sugar have negative effects while those of milk and milk products, vanaspati oil, eggs, and meat/fish/poultry have positive effects.

For an assessment of relative importance of expenditure and price effects, their elasticities were computed. To avoid repetition, our comments are selective and brief. ${ }^{17}$

Expenditure elasticities for the acutely poor in rural India rose sharply over the period 19932004 - from a little over 2 to $8 .{ }^{18}$ In other words, calorie share's sensitiveness to expenditure changes became substantially larger. By contrast, the elasticity was halved in urban India (from over 4 to over 2). Among the affluent, one difference was that they were negative and their absolute values fell more in rural India than in urban India. In both rural and urban India and in both 1993 and 2004, the (absolute) expenditure elasticities were considerably lower than for the acutely poor.

Confining to food price elasticities which had significant regression coefficients, an important finding is that while they vary between food commodities, across different subsamples, and over time, they are substantially lower (in absolute value) than expenditure elasticities, implying that expenditure has a much larger influence on calorie shares. Second, although small in values, among the acutely poor, calorie shares were most sensitive to changes in price of vegetables and least to price of pulses/nuts/others. Among the moderately poor and moderately affluent, cereal price elasticities are small but larger for the moderately affluent.

Over the period 1993-2004, significant changes occurred in each subsample. Among the acutely poor, for example, vanaspati oil price elasticity was largest and, in fact, slightly larger than among the affluent. But the moderately poor and moderately affluent exhibited slightly

\footnotetext{
${ }^{17}$ All elasticity comparisons are in terms of absolute values unless stated otherwise.

${ }^{18}$ Why these elasticities are so large is somewhat surprising. Details are given in the annex.
} 
larger elasticities. Milk price elasticity was negative among the acutely poor but positive among the affluent. Apart from being low, fruit price elasticities varied little among the subsamples. Vegetable price elasticities varied over a slightly larger range, with the highest among the moderately poor and lowest among the affluent. Cereal price elasticity is small but negative among the affluent.

The elasticities from the urban subsamples also vary in some respects. Among the acutely poor in 1993, the (absolute) elasticities were not uniformly low -for example, vegetable oil price elasticity. It was also larger than among the moderately poor and moderately affluent but about the same as among the affluent. Vegetable price elasticities, however, are low and vary over a small range among all except the acutely poor. Cereal price elasticities vary over a slightly larger range and are not so small, with the highest among the affluent.

2004 witnessed further changes. Cereal price elasticity among the acutely poor was slightly lower than among the affluent but not so small. However, vegetable oil price elasticity was largest among the acutely poor but smaller relative to 1993. Egg price elasticity varied over a small range but it was largest among the acutely poor. Elasticity of price of pulses/nuts/others was lowest among the acutely poor. Elasticity of meat/fish poultry price was not so low but only among the affluent.

In sum, while these elasticities point to the more important role of expenditure in determining calorie share of cereals, they nevertheless corroborate that food prices matter too.

\section{(iii) Estimates of Undernourished}

To facilitate comparison of results obtained using Lowess (with expenditure) and robust regression (with expenditure, demographic and caste characteristics and food prices), various calorie share of cereals thresholds and the implied estimates of undernourished are given below in Table 8 .

Graphical illustrations of the relationship between calorie share of cereals and MPCE, splicing together the results for the four subsets of acutely poor, moderately poor, moderately affluent and affluent, are given in the annex. ${ }^{19}$

\footnotetext{
${ }^{19}$ Note that in constructing these graphs and in determining the threshold values, we have not ignored the nonsignificant expenditure coefficients in a few cases. An advantage, however, is that the disaggregation by poverty status allows the coefficients of explanatory variables to vary.
} 
Table 8: Comparison of Calorie Share of Cereals Thresholds and Undernourished in India, 1993-2004

\begin{tabular}{|c|c|c|c|c|c|}
\hline Sample & $\begin{array}{l}\text { Calorie Share } \\
\text { of Cereals } \\
\text { Threshold }\end{array}$ & $\begin{array}{l}\text { Expenditure } \\
\text { Threshold }\end{array}$ & $\begin{array}{l}\text { Below } \\
\text { Expenditure } \\
\text { Threshold but } \\
\text { above Calorie } \\
\text { Threshold (\%) }\end{array}$ & $\begin{array}{l}\text { Above } \\
\text { Expenditure } \\
\text { Threshold but } \\
\text { above Calorie } \\
\text { Threshold } \\
\text { (\%) }\end{array}$ & $\begin{array}{l}\text { Total } \\
\text { Undernourished } \\
\text { (\% Share of } \\
\text { Population) } \\
(\%)\end{array}$ \\
\hline Rural 1993 & $\begin{array}{c}0.86 \\
(0.80)\end{array}$ & $\begin{array}{c}\text { Rs } 105.4 \\
\text { (Rs. 200.3) }\end{array}$ & $\begin{array}{c}0.05 \\
(2.64) \\
\end{array}$ & $\begin{array}{c}9.55 \\
(24.72) \\
\end{array}$ & $\begin{array}{c}9.60 \\
(27.36)\end{array}$ \\
\hline Urban 1993 & $\begin{array}{c}0.78 \\
(0.75)\end{array}$ & $\begin{array}{c}\text { Rs } 209.5 \\
\text { (Rs. 270.4) }\end{array}$ & $\begin{array}{c}0.24 \\
(1.21)\end{array}$ & $\begin{array}{c}9.05 \\
(13.37)\end{array}$ & $\begin{array}{c}9.29 \\
(14.58)\end{array}$ \\
\hline Urban 2004 & $\begin{array}{c}0.78 \\
(0.75)\end{array}$ & $\begin{array}{c}\text { Rs } 151.4 \\
\text { (Rs. 270.4) }\end{array}$ & $\begin{array}{c}0.01 \\
(1.04)\end{array}$ & $\begin{array}{c}4.89 \\
(7.56)\end{array}$ & $\begin{array}{c}4.90 \\
(8.60)\end{array}$ \\
\hline
\end{tabular}

1. Robust regression results are accompanied by Lowess results in parentheses.

The expenditure thresholds obtained from Lowess are considerably larger than those obtained from robust regression - almost twice as high for rural 1993, 1.7 times higher for urban 2004 and about 1.3 times higher for rural 2004 and urban 1993. The calorie thresholds obtained from Lowess are lower than those obtained from robust regressions. As a result, the estimates of undernourished vary greatly. Consider, for example, the estimates for rural India. The Lowess estimate is about three times greater than the robust regression estimate for 1993 and about two times greater for 2004. Besides, while the rate of reduction with robust regression is negligible, it contrasts with a sharp reduction in Lowess estimates. Similarly, for urban India, the estimate of undernourished from Lowess is about one and a half times greater than that obtained from robust regression for 1993 and about 1.7 times greater for 2004 .

In sum, what our analysis points to is that the Jensen-Miller (2011) story is of limited interest and potentially misleading principally because it confines variation in calorie share to a measure of wealth. The calorie threshold is suspect as it is influence by several other factors — especially food prices - that are omitted. Of particular interest is the finding that even acutely poor substitute in response to changes in food prices and, consequently, the calorie threshold changes. Besides, the estimates of undernourished are vitiated by the failure to distinguish between those who are above the calorie threshold at extremely low expenditures and those with much higher expenditures. As these changed differently over the period 19932004, and, arguably, call for different policies, the new measure has limited analytical and policy appeal. $^{20}$

\footnotetext{
${ }^{20}$ Why descriptive richness of an explanation matters and not just its predictive accuracy was persuasively argued by Sen (1980).
} 


\section{Concluding Observations}

Decline in calorie intake - especially from cereals-across all expenditure classes during a period of accelerated economic growth - is puzzling. Associated with the reduction in calorie intake is a related worry of a sharp rise in the proportion of calorie deprived relative to widely used calorie norms. Many remain sceptical of this finding on the grounds that the calorie norms are no longer relevant because of two significant changes: (i) improvements in the social epidemiology of disease, and (ii) life-style changes including less strenuous activity patterns. Since no estimates are given of what these changes imply in terms of reduction of calorie 'requirements', measurement of undernutrition remains fraught with difficulties. As illustrated, even if a substantial reduction in calorie requirements is allowed for, the proportion of undernourished rises during the period 1993-2004. So the new measure proposed by Jensen and Miller (2011), dispensing with calorie norms and relying on a behavioural approach, seemed promising. Our analysis, however, raises serious doubts about the calorie share of cereals/staples threshold as the basis of measurement of undernutrition. First, although the theoretical rationale of this measure is consistent with the results obtained for China - in particular, a constrained utility maximisation model with a penalty constraint that decreases as hunger diminishes - it is also consistent with a lexicographic preference for cereals/staples. The latter undermines the constrained utility maximisation model. Second, absence of food prices in constructing the calorie share threshold flies in the face of substantial evidence confirming substitution between food commodities even among the poor in response to changing prices. Indeed, assuming away of their taste for variety undermines the behavioural approach. Third, experiments with an expanded specification incorporating not just expenditure but also demographic and caste characteristics, and food prices for various commodities imply large differences in proportions of undernourished both in the same year and over time.

In conclusion, not just predictive accuracy of the new measure proposed but also its descriptive richness leave much to be desired. 


\section{Annexure}

\section{(i) Graphical Illustrations}

Figure A.1 gives graphs of calorie share of foodgrains with respect to monthly per capita expenditure in rural and urban India in 1993 and 2004, based on robust regressions.

Figure: A. 1 Calorie Share of Foodgrains by Monthly Per Capita Expenditure in Rural and Urban India, 1993-2004.
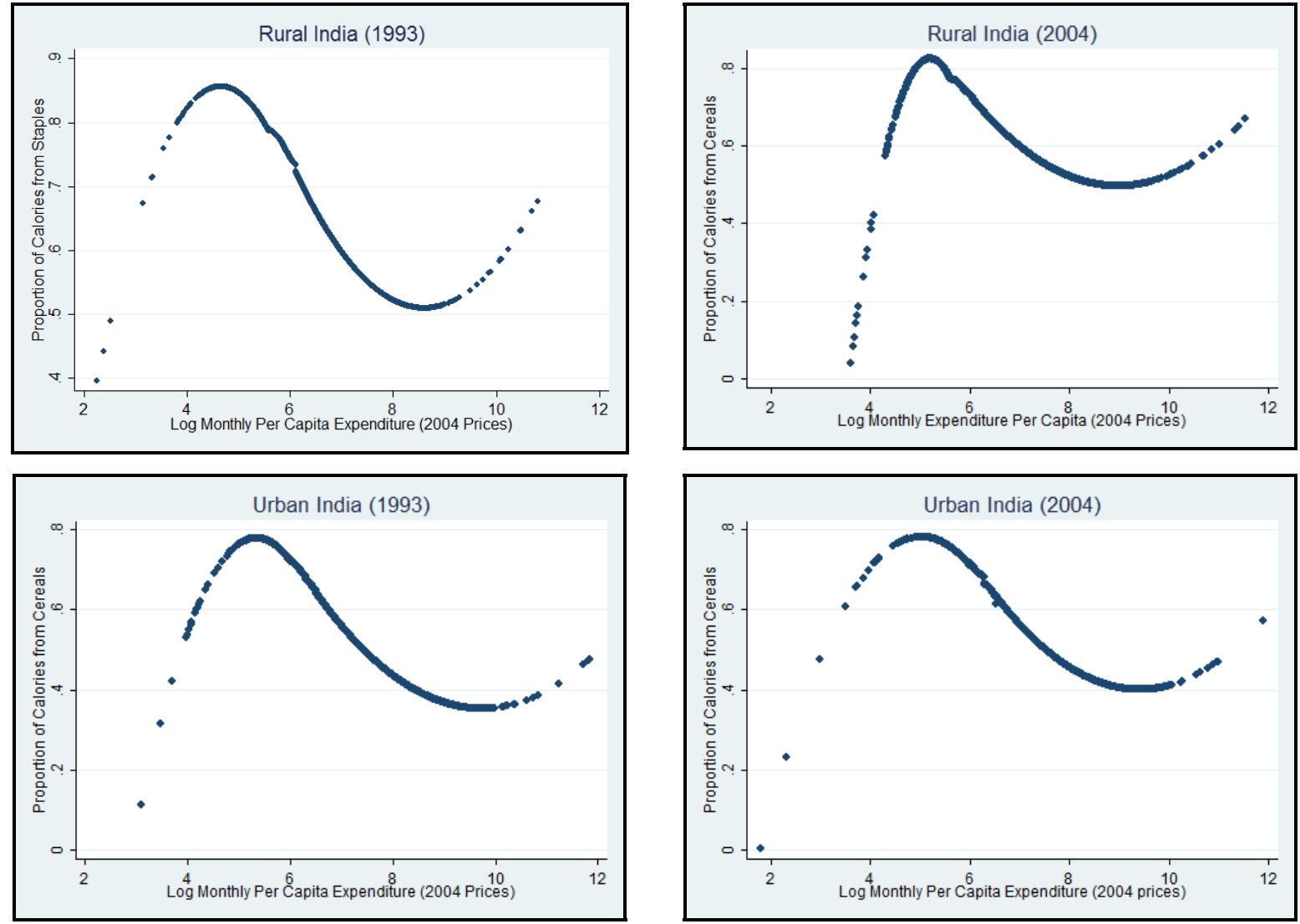


\section{(ii) Expenditure and Food Price Elasticities}

(iii)

Tables A.1-A.4 give expenditure and food price elasticities computed using robust regression.

Table A.1: Elasticities of Calorie Share of Foodgrains with respect to Food Prices and MPCE in Rural India, 1993

\begin{tabular}{|l|c|c|c|c|}
\hline & $\begin{array}{c}\text { Acutely } \\
\text { Poor }\end{array}$ & $\begin{array}{c}\text { Moderately } \\
\text { Poor }\end{array}$ & $\begin{array}{c}\text { Moderately } \\
\text { Affluent }\end{array}$ & Affluent \\
\hline MPCE & $2.061^{*}$ & 5.565 & -6.215 & $-1.622^{*}$ \\
\hline Price of Milk \& Milk Products & 0.001 & -0.002 & 0.000 & -0.003 \\
\hline Price of Vanaspati Oil & -0.018 & -0.015 & -0.014 & $-0.019^{*}$ \\
\hline Price of Sugar & -0.014 & -0.014 & -0.012 & 0.002 \\
\hline Price of Eggs & 0.001 & -0.002 & -0.004 & $0.011^{*}$ \\
\hline Price of Meat/Fish/Poultry & 0.004 & $0.008^{*}$ & -0.004 & -0.003 \\
\hline Price of Pulses/Nuts/Others & $-0.004^{*}$ & $-0.007^{*}$ & $-0.007^{*}$ & $-0.010^{*}$ \\
\hline Price of Fruits & 0.001 & 0.001 & 0.003 & $0.003^{*}$ \\
\hline Price of Vegetables & $0.022^{*}$ & $0.013^{*}$ & $0.014^{*}$ & $0.017^{*}$ \\
\hline Price of Cereals & 0.009 & $0.013^{*}$ & $0.024^{*}$ & 0.004 \\
\hline
\end{tabular}

*Denotes significant regression coefficient.

Table A.2: Elasticities of Calorie Share of Foodgrains with respect to Food Prices and MPCE in Rural India, 2004

\begin{tabular}{|l|c|c|c|c|}
\hline & $\begin{array}{c}\text { Acutely } \\
\text { Poor }\end{array}$ & $\begin{array}{c}\text { Moderately } \\
\text { Poor }\end{array}$ & $\begin{array}{c}\text { Moderately } \\
\text { Affluent }\end{array}$ & Affluent \\
\hline MPCE & $8.437^{*}$ & $7.502^{*}$ & 5.544 & $-1.294^{*}$ \\
\hline Price of Milk \& Milk Products & $-0.005^{*}$ & -0.002 & -0.002 & $0.012^{*}$ \\
\hline Price of Vanaspati Oil & $0.036^{*}$ & $0.045^{*}$ & $0.049^{*}$ & $0.031^{*}$ \\
\hline Price of Sugar & -0.017 & -0.006 & -0.009 & $-0.050^{*}$ \\
\hline Price of Eggs & 0.011 & $0.008^{*}$ & 0.006 & $-0.005^{*}$ \\
\hline Price of Meat/Fish/Poultry & 0.005 & -0.001 & 0.005 & $0.006^{*}$ \\
\hline Price of Pulses/Nuts/Others & -0.004 & -0.003 & $-0.005^{*}$ & -0.001 \\
\hline Price of Fruits & $0.015^{*}$ & $0.012^{*}$ & $0.014^{*}$ & $0.014^{*}$ \\
\hline Price of Vegetables & $0.014^{*}$ & $0.024^{*}$ & $0.021^{*}$ & $0.006^{*}$ \\
\hline Price of Cereals & -0.011 & -0.001 & -0.008 & $-0.051^{*}$ \\
\hline
\end{tabular}

*Denotes significant regression coefficient. 
Table A.3: Elasticities of Calorie Share of Foodgrains with respect to Food Prices and MPCE in Urban India, 1993

\begin{tabular}{|l|c|c|c|c|}
\hline & $\begin{array}{c}\text { Acutely } \\
\text { Poor }\end{array}$ & $\begin{array}{c}\text { Moderately } \\
\text { Poor }\end{array}$ & $\begin{array}{c}\text { Moderately } \\
\text { Affluent }\end{array}$ & Affluent \\
\hline MPCE & $4.077^{*}$ & 1.273 & 5.653 & $-1.853^{*}$ \\
\hline Price of Milk \& Milk Products & $-0.020^{*}$ & -0.001 & 0.003 & $0.036^{*}$ \\
\hline Price of Vanaspati Oil & $-0.125^{*}$ & $-0.083^{*}$ & $-0.044^{*}$ & $-0.111^{*}$ \\
\hline Price of Sugar & -0.005 & -0.017 & 0.001 & -0.001 \\
\hline Price of Eggs & 0.004 & $0.014^{*}$ & 0.006 & $0.014^{*}$ \\
\hline Price of Meat/Fish/Poultry & 0.003 & -0.003 & -0.011 & 0.018 \\
\hline Price of Pulses/Nuts/Others & $-0.016^{*}$ & $-0.018^{*}$ & $-0.027^{*}$ & $-0.032^{*}$ \\
\hline Price of Fruits & -0.002 & -0.007 & 0.000 & -0.003 \\
\hline Price of Vegetables & 0.008 & $-0.019^{*}$ & $-0.015^{*}$ & $-0.012^{*}$ \\
\hline Price of Cereals & 0.012 & $0.032^{*}$ & $0.034^{*}$ & $-0.079^{*}$ \\
\hline
\end{tabular}

* Denotes significant regression coefficient.

Table A.4: Elasticities of Calorie Share of Foodgrains with respect to Food Prices and MPCE in Urban India, 2004

\begin{tabular}{|l|c|c|c|c|}
\hline & $\begin{array}{c}\text { Acutely } \\
\text { Poor }\end{array}$ & $\begin{array}{c}\text { Moderately } \\
\text { Poor }\end{array}$ & $\begin{array}{c}\text { Moderately } \\
\text { Affluent }\end{array}$ & Affluent \\
\hline MPCE & $2.284^{*}$ & -8.187 & 12.362 & $-1.812^{*}$ \\
\hline Price of Milk \& Milk Products & 0.003 & 0.002 & $0.009^{*}$ & $0.008^{*}$ \\
\hline Price of Vanaspati Oil & $0.093^{*}$ & $0.041^{*}$ & 0.009 & $0.025^{*}$ \\
\hline Price of Sugar & -0.019 & $-0.049^{*}$ & $-0.092^{*}$ & $-0.085^{*}$ \\
\hline Price of Eggs & $0.023^{*}$ & $0.023^{*}$ & $0.021^{*}$ & $0.019^{*}$ \\
\hline Price of Meat/Fish/Poultry & 0.006 & 0.004 & 0.006 & $0.021^{*}$ \\
\hline Price of Pulses/Nuts/Others & $-0.006^{*}$ & $-0.008^{*}$ & $-0.012^{*}$ & 0.000 \\
\hline Price of Fruits & $0.010^{*}$ & $0.015^{*}$ & $0.008^{*}$ & 0.004 \\
\hline Price of Vegetables & 0.006 & $0.011^{*}$ & 0.011 & $-0.008^{*}$ \\
\hline Price of Cereals & $-0.074^{*}$ & $-0.054^{*}$ & $-0.051^{*}$ & $-0.099^{*}$ \\
\hline
\end{tabular}

* Denotes significant regression coefficient. 


\section{References}

Behrman, J. and A. Deolalikar (1989) "Is Variety the Spice of Life? Implications for Calorie Intake”, The Review of Economics and Statistics, vol. 71, no. 4.

Dasgupta, P. (1993) An Inquiry into Well-Being and Destitution, Oxford: Clarendon press.

Deaton, A. (1995) The Analysis of Household Surveys: A Microeconomic Approach to Development Policy, Baltimore, Maryland: The Johns Hopkins University Press.

Deaton, A., and J. Dreze (2009), 'Food and Nutrition in India: Facts and Interpretations', Economic and Political Weekly, XLIV(7), 42-65.

Gaiha, R., R. Jha and Vani S. Kulkarni (2010) "Prices, Expenditure and Nutrition in India”, Canberra: Australian National University, ASARC Working Paper 2010/15.

Gopalan, C., B. Sastri, and S. Balasubramanian (1971), Nutritive Value of Indian Foods, National institute of Nutrition: Indian Council of Medical Research: Hyderabad.

Jensen, R. T., and N. H. Miller (2011) “A Revealed Preference Approach to Measuring Hunger and Undernutrition”, mimeo.

Kaicker, N., Vani S. Kulkarni and R. Gaiha “ Dietary Transition in India: An Analysis Based on NSS Data for 1993 and 2004”, A paper for presentation at the World Congress of the International Economic Association, Beijing, July, 2011.

Sen, Amartya "Description as Choice”, Oxford Economic Papers, vol. 32, no. 3.

Srinivasan, T.N., (1992), 'Undernutrition: Concepts, Measurements and Policy Implications', in: S.R. Osmani (ed.), Nutrition and Poverty, Clarendon Press, Oxford, pp. 97-120.

Svedberg, P. (2000) Poverty and Undernutrition, Oxford: Oxford University Press.

Timmer, C. P. (1981) "Is There “Curvature” in the Slutsky Matrix?”, The Review of Economics and Statistics, vol. 63, no. 3. 